\title{
ADJUSTMENT OF THE FLOW OF TISSUE FLUID IN THE PRES- ENCE OF LOCALIZED, SUSTAINED HIGH VENOUS PRESSURE AS FOUND WITH VARICES OF THE GREAT SAPHENOUS SYSTEM DURING WALKING
}

\author{
By HENRY K. BEECHER \\ (From the Surgical Laboratorics of the Hariard Medical School at the Massachusetts General \\ Hospital, Boston)
}

(Received for publication April 21, 1937)

Varices of the saphenous systems of veins are a consequence of the inadequate valves present and the resulting imperfect circulation. Altered venous pressure relationships as one phase of this impaired circulation have heretofore received little attention. The extremely abnormal pressure relationships found in varicose veins, appear only during activity. The only method worked out for measuring the fluctuating venous pressure of exercise at the ankle, is that of Beecher, Field and Krogh (1). This method has been applied in the present study to a consideration of venous pressures during light and moderate exercise (walking) in patients with severe varices of the great saphenous system of veins. The pressure relationships found have been compared with those of normal subjects. The data obtained have been considered from the point of view of Starling's concept of the formation of tissue fluid and the formation of lymph.

The method for determining the fluctuating venous pressure has been described (1). Further experience with the method has made it possible to shorten appreciably the time of a determination. This is accomplished by minor changes of the apparatus and procedure. No change of principle has been found necessary. The revised method will be described briefly.

\section{APPARATUS AND METHOD}

With each step, the venous pressure at the ankle fluctuates; this occurs as a consequence of weight bearing, or the squeezing of veins by muscles. To determine the venous pressure during walking, a maximum pressure $(P s)$ and a minimum pressure $(P d)$ must be determined during the step. These are analogous to systolic and diastolic pressures. It is also of interest to determine the pressure in the veins at rest immediately after the cessation of walking $(\mathrm{Po})$, and the pressure after fifteen minutes of motionless standing $\left(P_{15}\right)$. In considering normal subjects it has been shown (1) that the degree of exer- cise as well as the rate has an important effect on the venous pressure and on the pressure gradient from arteriolar to venous end of the capillary; accordingly, a standing (i.e. non-progressing) walk at two differing degrees of effort at the rate of forty steps per minute was used. Light exercise consisted in a standing walk at this rate, employing a low step with relaxed ankle, in which the ball of the foot was barely raised from the floor. Moderate exercise was obtained by a high step at the same rate; here, the foot was raised with relaxed ankle so that the toes were $10 \mathrm{~cm}$. and the heel $25 \mathrm{~cm}$. from the floor. A uniform step is very important; failure in uniformity, requires repetition of the experiment. Before each experiment the subject must take at least 10 steps to acquire uniformity and to allow for major adjustments of the deep circulation. Fatigue must be guarded against by frequent rest periods.

The modified apparatus is shown in Figures 1 and 2. A celluloid capsule $1.7 \mathrm{~cm}$. wide and $0.7 \mathrm{~cm}$. deep was sealed with celloidin to one of the prominent ankle veins, usually the prolongation of the great saphenous where it sweeps anterior to and just above the internal malleolus. A bony background, free from moving tendons, is best. The capsule (1) must be attached so well that at no time during an experiment will the edges separate and allow the flange of celloidin against the skin to act as a bellows with each step. If this occurs, the results are incorrect; consequently, the capsule must be examined before removal from the ankle to make certain this has not taken place. A flexible rubber tube of $1.5 \mathrm{~mm}$. bore and $1 \mathrm{~mm}$. wall thickness, 1.5 meters long was attached to the capsule. A short loop of this was caught against the leg with adhesive tape to take all tension off the capsule, and the other end attached to the proximal arm of a water manometer (2) made of glass tubing of $3.0 \mathrm{~mm}$. bore. Each arm was 1.5 meters long. The manometer was filled with water to a height of $65 \mathrm{~cm}$. This was fixed against a centimeter scale (3). A mercury reservoir (4) was arranged, as shown, in order that the air pressure in the system might be increased to any desired level. The distal end of the manometer was connected through rubber tubing $40 \mathrm{~cm}$. long, and of the same dimensions as those given above, to a recording device (7). This recorder was made by cutting off a $3 \mathrm{~cm}$. length of the barrel of a well fitting syringe and inserting in it a $1.7 \mathrm{~cm}$. length of the piston. An air filled syringe (6) was inserted into the line connecting the water manometer with 


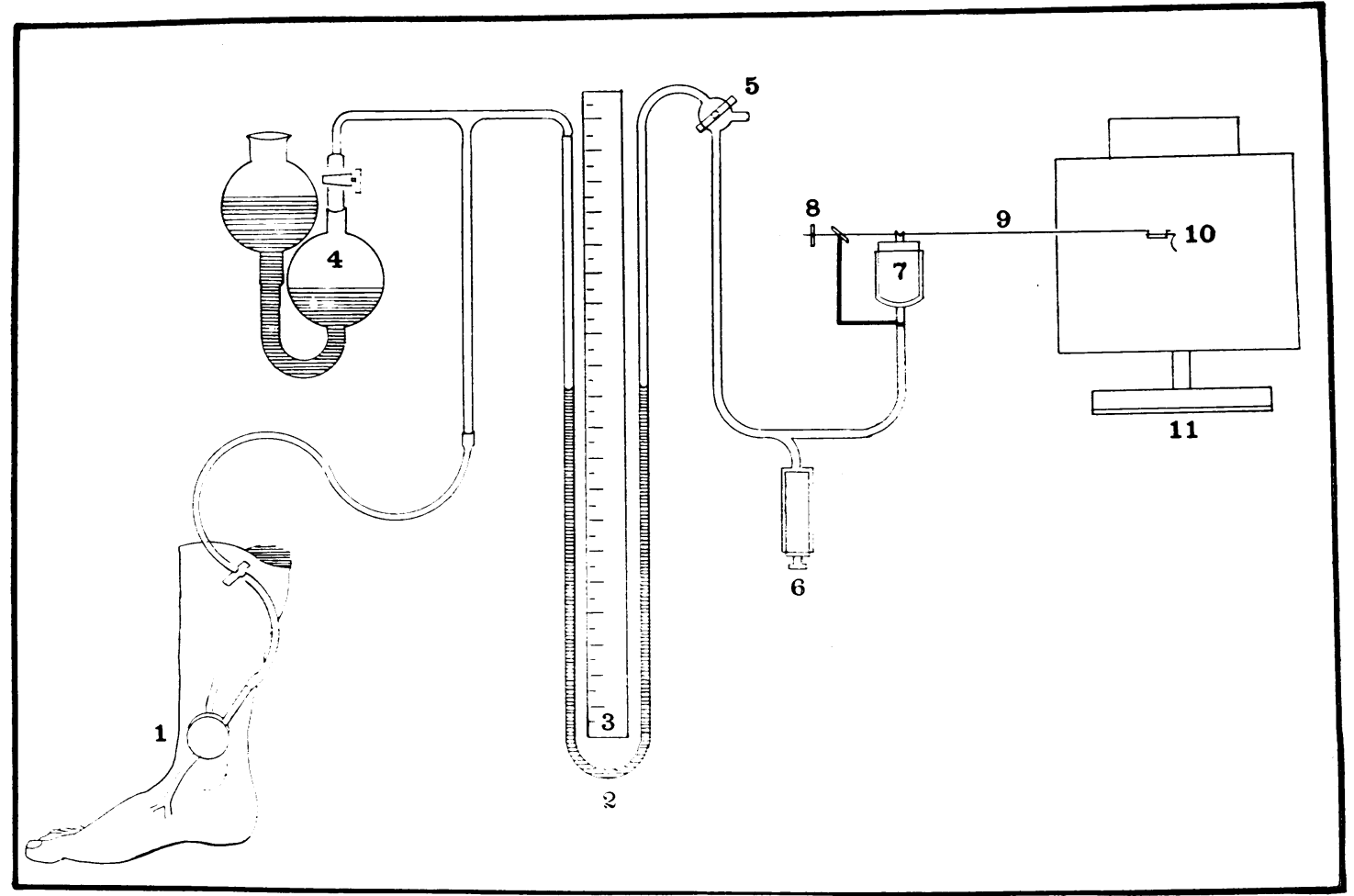

Fig. 1. Apparatus for Measuring Venols Presslre dering Walking

1, Capsule; 2, Manometer; 3, Scale; 4, Mercury reservoir; 5, Stopcock; 6, Air-filled syringe; 7, Piston recorder; 8, Counterbalance: 9, Hollow aluminum tube writing arm: 10, Steel wire writing point; 11, Kymograph.

the piston recorder; this was used to set the writing point, a hanging steel wire (10) at any desired level. The writing point was suspended from and freely movable in a plane perpendicular to a fine aluminum tube (9), about $1.0 \mathrm{~mm}$. in diameter. This must be attached to the piston of the syringe and then carefully counterbalanced (8).

The maximum pressure $(P s)$ can be determined in two ways. Previous work has shown that the two methods agree excellently; therefore only one (the direct) was employed in this study. Occasionally it was confirmed by the indirect. First, it is possible to measure $P s$ by direct observation. One observer watches the vein through the capsule (cross lighting increases the accuracy here) while another elevates the pressure in the system by raising the mercury reservoir. Finally, a point is reached as the pressure rises, where the blood flows only during the moment the tensed foot and leg are bearing all the subject's weight. The moment of maximum pressure occurs just before the foot is raised. When the foot is elevated, the vein blanches. When near the endpoint a further increase of intracapsular pressure of 1 to $3 \mathrm{~cm}$. H.. $\mathrm{O}$ prevents the flow even during the moment of weight bearing, i.e., the moment of maximum venous pressure. This point can be checked easily by the same or another individual to within $3 \mathrm{~cm}$. of water.
I's can be determined by a second, and in this case objective, method. If a high pressure is introduced into the system and then gradually lowered while the subject walks, it should be possible to find $P s$ by observing the pressure at which waves begin to come through on the kymograph (11). Practically, one must accept the fact that however carefully the location of the capsule is chosen, there will be some motion of the underlying tissues with each step, some change in the intracapsular pressure which is not due to blood flow. This will be refiected on the kymograph as a curve of constant shape and amplitude. Now, if the pressure is gradually lowered, a point will be reached where the shape and amplitude of the curve shows a sharp change, due to the onset of blood flow through the vein imprisoned by the capsule. This represents $P s$ and agrees very well with it as determined by the direct method.

To determine the minimum pressure $(P d)$ in the vein during the step, one starts with a relatively high pressure, say near Ps, and gradually lowers it. As the pressure is lowered the volume of the fluctuations of the vein underlying the capsule increases and is recorded as a curve of greater amplitude on the kymograph. Finally, this passes through a maximum and begins to decrease even though the intracapsular pressure continues to fall. By obtaining short sections of curve, about 25 steps long, for 


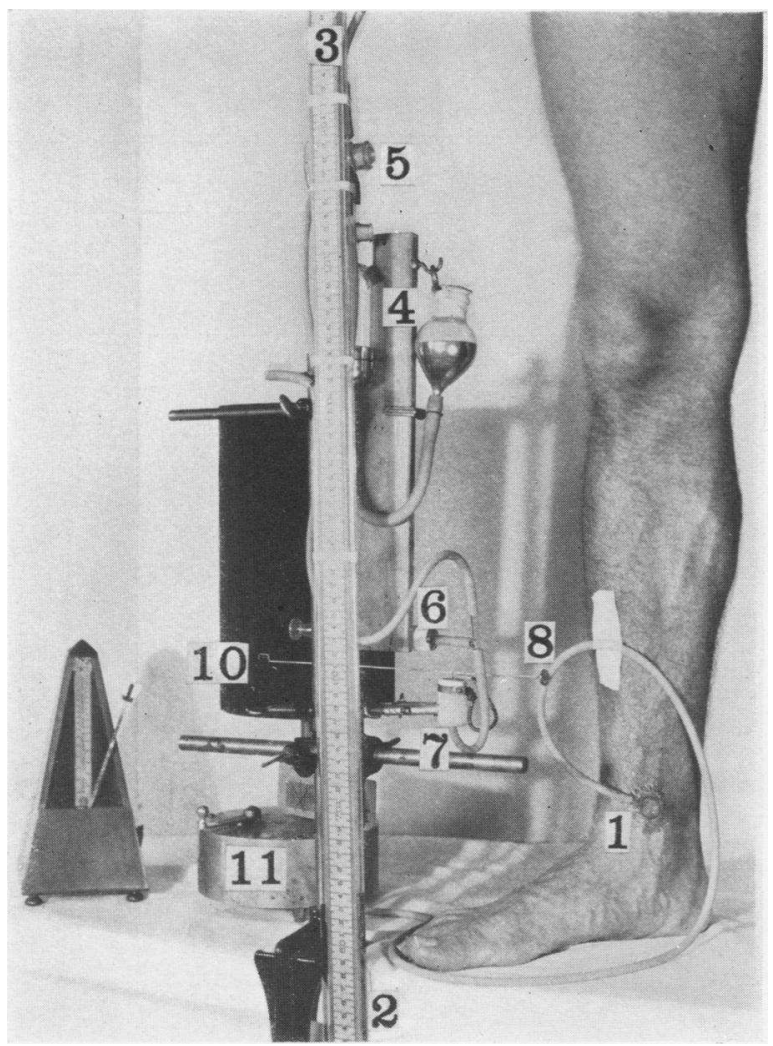

Fig. 2. Apparatis for Measuring Venols Presslre DLRING WALKING

1, Capsule ; 2, Manometer ; 3, Scale; 4, Mercury reservoir; 5, Stopcock; 6, Air-filled syringe; 7 , Piston recorder; 8, Counterbalance; 10 , Steel wire writing point ; 11, Kymograph.

each $5 \mathrm{~cm} . \mathrm{H}_{2} \mathrm{O}$ the pressure is lowered in the system; this point can be demonstrated sharply in a normal individual. It is convenient to have the kymograph going at slow speed so that the tracing of 25 steps will be condensed into about $1.5 \mathrm{~cm}$. length. If, between each section of tracing, stopcock 5 is opened to the atmosphere while the pressure in the system is readjusted, the writing point will remain at a constant level and the time of adjusting this will be saved. The pressure at which the maximum fluctuation of the curve occurs represents the minimum venous pressure, for at this point the maximum filling and emptying of the vein occurs during the step. If the intracapsular pressure be increased above this point the vein cannot fill completely, and the amplitude of fluctuation is less: a smaller fluctuation also occurs if the intracapsular pressure be lowered below the critical point. In this case, the smaller fluctuation is due to the fact that the vein does not empty completely; so the critical point (at which maximum filling and emptying of the section of vein imprisoned by the capsule occur) represents the minimum pressure in the vein during walking. In normal subjects this can be determined to within $5 \mathrm{~cm}$.
$\mathrm{H}_{2} \mathrm{O}$ pressure, and usually within $3 \mathrm{~cm}$. In cases with varicose veins, in which the venous pressure fluctuation is lacking, there will be during the course of the experiment, a gradual alteration in the curve due to changing pressure within the capsule; but in these cases even a slight change in amplitude is spread out over a wide pressure range and has no similarity to the sharp end-point which is present when a truly fluctuating venous pressure exists.

With a little practice $P o$ can be determined one second after the cessation of walking. The pressure in the ankle veins after the patient had been standing motionless equally on both feet for 15 minutes, $P_{15}$, was obtained without backboard support. This is of use in studying the effect of "involuntary" muscular activity.

Pertinent data regarding the normal individuals and those with varicose veins are listed in Tables I and II. The subjects were loosely clothed. Studies were started only after a 30 minute preliminary rest period. All determinations were made on barefoot subjects, and, in those with varicose veins, on the ones in whom valves of the great saphenous system could not be demonstrated clinically and in whom gross edema was not present. This choice was made since clinical edema in uncomplicated cases of varices is the exception. The rate and quantity of edema formation in the dependent legs of subjects sitting for 2 hours has been measured. Normals have been compared with uncomplicated cases with varicose veins. The edema formation is essentially the same in both groups, unless the perforating veins are incompetent.

\section{DISCESSION}

The clata in Table I indicate that in normal subjects a fluctuating pressure occurs in the great saphenous system of veins at the ankle. During light exercise this rises to $75 \mathrm{~cm}$. $\mathrm{H}_{2} \mathrm{O}$, well above the colloid osmotic pressure of the blood $\left(40 \mathrm{~cm} . \mathrm{H}_{2} \mathrm{O}\right)$, but persists at this high level for only one-third of the time required for the step (2). During two-thirds of the time required for the step the pressure of $28 \mathrm{~cm} . \mathrm{H}_{2} \mathrm{O}$ is well below the colloid osmotic pressure of the blood, and the conditions are suitable for the absorption of tissue fluid. With increasing severity of exercise, the pressures are even more favorable for absorption of tissue fluid directly into the venous end of the capillaries; any fluid not so absorbed is carried off by the lymphatics. These points have been discussed elsewhere (2) and are recalled here in order to emphasize the differences encountered when dealing with varicosities of the saphenous system. (See Table II.) The most striking abnormality is the persistently high and non-fluctuating pressure in the veins. During light exercise it persists at $96 \mathrm{~cm} . \mathrm{H}_{2} \mathrm{O}$. The sus- 
TABLE I*

Normal subjects

(Pressures in $\mathrm{cm} . \mathrm{H}_{2} \mathrm{O}$ at ankle level. Average height of heart to mid capsule $125 \mathrm{~cm}$.)

\begin{tabular}{|c|c|c|c|c|c|c|c|c|c|c|}
\hline \multirow[b]{2}{*}{ Subject } & \multirow[b]{2}{*}{ Sex } & \multicolumn{4}{|c|}{ Light exercise (Walking) } & \multicolumn{4}{|c|}{ Moderate exercise (Walking) } & \multirow{2}{*}{$\begin{array}{c}\text { Resting } \\
\text { pressure, } \\
15 \text { minute } \\
\text { standing } \\
P_{1 ;}\end{array}$} \\
\hline & & $\begin{array}{c}\text { Maximum } \\
\text { pressure } \\
P_{s}\end{array}$ & $\begin{array}{c}\underset{\text { pressure }}{\text { Minimum }} \\
P_{d}\end{array}$ & $\begin{array}{c}\text { Resting } \\
\text { pressure } \\
0 \text { time } \\
P_{o}\end{array}$ & $\begin{array}{c}\text { Pulsation } \\
\text { pressure } \\
P_{s}-P_{d}\end{array}$ & $\begin{array}{c}\text { Maximum } \\
\text { pressure } \\
P_{s}\end{array}$ & $\begin{array}{c}\text { Minimum } \\
\text { pressure } \\
P_{d}\end{array}$ & $\begin{array}{c}\text { Resting } \\
\text { pressure } \\
0 \text { time } \\
P_{0}\end{array}$ & $\begin{array}{c}\text { Pulsation } \\
\text { pressure } \\
P_{s}-P_{d}\end{array}$ & \\
\hline $\begin{array}{l}\text { H. B....... } \\
\text { M. N. . . . }\end{array}$ & $\sigma^{\pi}$ & $\begin{array}{r}69 \\
72 \\
100 \\
108\end{array}$ & $\begin{array}{l}30 \\
30 \\
34 \\
26\end{array}$ & $\begin{array}{l}62 \\
54 \\
67 \\
71\end{array}$ & $\begin{array}{l}39 \\
42 \\
66 \\
82\end{array}$ & $\begin{array}{l}41 \\
46 \\
62 \\
69\end{array}$ & $\begin{array}{l}21 \\
21 \\
21 \\
20\end{array}$ & $\begin{array}{l}40 \\
42 \\
45 \\
52\end{array}$ & $\begin{array}{l}18 \\
22 \\
39 \\
49\end{array}$ & $\begin{array}{l}111 \\
119 \\
120\end{array}$ \\
\hline C. T.......... & $\sigma^{7}$ & $\begin{array}{l}51 \\
59\end{array}$ & $\begin{array}{l}15 \\
10\end{array}$ & $\begin{array}{l}45 \\
48\end{array}$ & $\begin{array}{l}36 \\
49\end{array}$ & $\begin{array}{l}46 \\
50\end{array}$ & $\begin{array}{r}10 \\
9\end{array}$ & $\begin{array}{l}41 \\
39\end{array}$ & $\begin{array}{l}36 \\
42\end{array}$ & 95 \\
\hline O. B............. & $\sigma^{x}$ & $\begin{array}{l}105 \\
107\end{array}$ & $\begin{array}{l}30 \\
35\end{array}$ & $\begin{array}{l}96 \\
81\end{array}$ & $\begin{array}{l}75 \\
72\end{array}$ & $\begin{array}{l}66 \\
62\end{array}$ & $\begin{array}{l}18 \\
24\end{array}$ & $\begin{array}{l}63 \\
52\end{array}$ & $\begin{array}{l}46 \\
38\end{array}$ & \\
\hline A. K. . . . . . . . & $\sigma^{7}$ & 69 & 20 & 63 & 49 & 72 & 21 & 60 & 52 & 106 \\
\hline G. B. H.. & 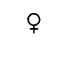 & $\begin{array}{l}72 \\
61\end{array}$ & $\begin{array}{l}33 \\
36\end{array}$ & $\begin{array}{l}58 \\
57\end{array}$ & $\begin{array}{l}39 \\
25\end{array}$ & $\begin{array}{l}55 \\
51\end{array}$ & $\begin{array}{l}25 \\
25\end{array}$ & $\begin{array}{l}44 \\
48\end{array}$ & $\begin{array}{l}28 \\
28\end{array}$ & 102 \\
\hline M. F....... & q & $\begin{array}{l}59 \\
63\end{array}$ & $\begin{array}{l}24 \\
27\end{array}$ & $\begin{array}{l}54 \\
56\end{array}$ & $\begin{array}{l}35 \\
36\end{array}$ & $\begin{array}{l}45 \\
53\end{array}$ & $\begin{array}{l}18 \\
15\end{array}$ & $\begin{array}{l}43 \\
48\end{array}$ & $\begin{array}{l}27 \\
36\end{array}$ & $\begin{array}{l}108 \\
108\end{array}$ \\
\hline M. B........ & 우 & $\begin{array}{l}84 \\
71\end{array}$ & $\begin{array}{l}25 \\
22\end{array}$ & $\begin{array}{l}71 \\
64\end{array}$ & $\begin{array}{l}59 \\
49\end{array}$ & $\begin{array}{l}49 \\
53\end{array}$ & $\begin{array}{l}17 \\
18\end{array}$ & $\begin{array}{l}38 \\
40\end{array}$ & $\begin{array}{l}35 \\
33\end{array}$ & 109 \\
\hline J. M... & 운 & $\begin{array}{l}85 \\
86\end{array}$ & $\begin{array}{l}50 \\
47\end{array}$ & $\begin{array}{l}75 \\
76\end{array}$ & $\begin{array}{l}35 \\
39\end{array}$ & $\begin{array}{l}68 \\
66\end{array}$ & $\begin{array}{l}34 \\
32\end{array}$ & $\begin{array}{l}63 \\
65\end{array}$ & $\begin{array}{l}34 \\
35\end{array}$ & \\
\hline $\begin{array}{l}\text { B. K. . . . . . } \ldots \ldots \ldots \\
\text { Average (to nearest un }\end{array}$ & $\begin{array}{c}\text { } \\
\text { it) } . \text {. }\end{array}$ & $\begin{array}{l}62 \\
69 \\
75\end{array}$ & $\begin{array}{l}17 \\
18 \\
28\end{array}$ & $\begin{array}{l}54 \\
49 \\
63\end{array}$ & $\begin{array}{l}45 \\
51 \\
49\end{array}$ & $\begin{array}{l}62 \\
64 \\
57\end{array}$ & $\begin{array}{l}14 \\
11 \\
20\end{array}$ & $\begin{array}{l}63 \\
53 \\
49\end{array}$ & $\begin{array}{l}46 \\
49 \\
36\end{array}$ & 109 \\
\hline
\end{tabular}

* Adapted from Beecher, Field and Krogh (1).

tained pressure in the varicosities is more than twice the normal colloid osmotic pressure of the blood and a gross positive filtration pressure of the order of $50 \mathrm{~cm}$. $\mathrm{H}_{2} \mathrm{O}$ is evident, yet in the cases studied gross edema was not present.

It was shown (loc. cit.) that with increasing exercise a more efficient circulation was provided for by a marked steepening of the pressure gradient from the arteriolar to the venous end of the capillary. With varicosities this is lacking insofar as it is a result of lowered venous pressure. With increasing exercise a tremendous increase in washing of the tissues with reabsorption of much of the tissue fluid directly into the capillary is provided for normally $(2,5,6,7,10)$.

With varicosities a sustained high filtration pressure exists; thus the great burden of removing tissue fluid must fall on the lymphatics. The lymphatics appear to provicle the compensating mechanism which permits such high filtration pressures to exist without gross edema. It is probable that in the failure of this compensating mechanism some explanation of the severe complications of varices can be found.

It will be useful to consider the data from the viewpoint of Starling's theory (11) of the formation of tissue fluid. In its simplest form this theory considers that the movement of fluid across the capillary wall is the resultant of two opposing forces, the colloid osmotic pressure of the plasma tending to draw fluid into the vessel and the hydrostatic pressure tending to force it out. This concept holds true if one remembers that the effective pressures are the net pressures between the inside and the outside of the capillary and if one regards what Peters (9) calls the "subtle implications" of the theory: that the end results may be influenced by variable capillary permeability, by tissue elasticity and by lymph flow. The reasons why all three of these are of importance 
in the case under consideration will be pointed out.

In the tissues drained by the superficial system of leg veins a condition exists which is comparable in some respects to that found in the presence of prolonged and marked venous obstruction. Landis (6) has shown that venous obstruction is followed by elevation of arteriolar capillary pressure to a height greater than that producing the constriction, in the case of a recumbent subject with hand at the level of the manubrium sterni. Thompson, Thompson and Dailey (12) have shown that standing still results in the escape of what they describe as approximately protein-free fluid from the capillaries to the leg tissue with increase in leg size. Youmans et al. (14) have confirmed the increase of the size of the legs with standing. Landis et al. (8) have shown that when the venous pressure exceeded $60 \mathrm{~mm} . \mathrm{Hg}(81 \mathrm{~cm}$. $\mathrm{H}_{2} \mathrm{O}$ ), protein in an appreciable quantity escaped. At a venous pressure of $80 \mathrm{~mm}$. $\mathrm{Hg}(108 \mathrm{~cm}$. $\mathrm{H}_{2} \mathrm{O}$ ), protein was lost in an amount which indicated that the capillary filtrate contained an aver- age of 1.5 per cent protein. This, of course, would facilitate the loss of fluid from the blood and would tend to increase the gross filtration pressure of $50 \mathrm{~cm} . \mathrm{H}_{2} \mathrm{O}$ referred to above, since it would act outside the capillary. von Farkas (3) and Govaerts (4) estimate that 1 per cent serum albumin produces an osmotic pressure of 6 to $8 \mathrm{~cm} . \mathrm{H}_{2} \mathrm{O}$.

In brief, important forces or conditions tending to produce tissue fluid here are hydrostatic pressure (gravity tends to produce filtration at the arterial end and to prevent reabsorption at the venous end of the capillary) and the consequences of increased capillary permeability. Those tending to oppose the production of tissue fluid are concerned chiefly with increasing the colloid osmotic pressure of the blood. Such increase is probably of little effect. It can be explained as a result of plasma concentration due to accelerated filtration and to acidification of the blood due to the loss of oxygen and accumulation of carbon dioxide causing the red blood cells to withdraw fluid from the plasma, as pointed out by Peters.

TABLE II

Subjects with varicose veins

(Pressures in $\mathrm{cm} . \mathrm{H}_{2} \mathrm{O}$ at ankle level)

\begin{tabular}{|c|c|c|c|c|c|c|c|c|c|c|c|}
\hline \multirow[b]{2}{*}{ Subject } & \multirow[b]{2}{*}{ Sex } & \multirow{2}{*}{$\begin{array}{l}\text { Height } \\
\text { of heart } \\
\text { to mid- } \\
\text { capsule }\end{array}$} & \multicolumn{4}{|c|}{ Light exercise (Walking) } & \multicolumn{4}{|c|}{ Moderate exercise (Walking) } & \multirow{2}{*}{ 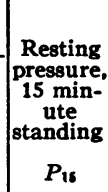 } \\
\hline & & & $\begin{array}{c}\text { Maxi- } \\
\text { mum } \\
\text { pres- } \\
\text { sure } \\
P_{8}\end{array}$ & $\begin{array}{c}\underset{\text { pressure }}{\text { Minimum }} \\
P_{d}\end{array}$ & $\begin{array}{c}\text { Resting } \\
\text { pres- } \\
\text { sure } \\
0 \text { time } \\
P_{\bullet}\end{array}$ & $\begin{array}{c}\text { Pulsa- } \\
\text { tion } \\
\text { pres- } \\
\text { sure } \\
P_{z}-P_{d}\end{array}$ & $\begin{array}{c}\text { Maxi- } \\
\text { mum } \\
\text { pres- } \\
\text { sure } \\
P_{\text {. }}\end{array}$ & $\begin{array}{c}\underset{\text { pressure }}{\text { Minimum }} \\
\boldsymbol{P}_{\boldsymbol{d}}\end{array}$ & $\mid \begin{array}{c}\text { Resting } \\
\text { pres- } \\
\text { sure } \\
0 \text { time } \\
P_{0}\end{array}$ & $\mid \begin{array}{c}\text { Pulsa- } \\
\text { tion } \\
\text { pres- } \\
\text { sure } \\
P_{s}-P_{d}\end{array}$ & \\
\hline J. B....... & $0^{7}$ & $\begin{array}{l}c m . \\
119\end{array}$ & $\begin{array}{l}110 \\
113\end{array}$ & Same as maximum pressure & $\begin{array}{l}93 \\
93\end{array}$ & $\mathbf{0}$ & $\begin{array}{r}93 \\
101\end{array}$ & Same as maximum pressure & $\begin{array}{l}80 \\
82\end{array}$ & $\mathbf{0}$ & $\begin{array}{l}109 \\
110\end{array}$ \\
\hline M.M... & $\sigma^{\prime}$ & 120 & $\begin{array}{l}83 \\
89\end{array}$ & Same as maximum pressure & $\begin{array}{l}81 \\
85\end{array}$ & 0 & $\begin{array}{l}77 \\
85\end{array}$ & Same as maximum pressure & $\begin{array}{l}77 \\
81\end{array}$ & o & $\begin{array}{l}93 \\
99\end{array}$ \\
\hline C. G.. & $\sigma^{x}$ & 127 & $\begin{array}{l}114 \\
117\end{array}$ & Same as maximum pressure & $\begin{array}{l}104 \\
104\end{array}$ & $\mathbf{0}$ & $\begin{array}{l}110 \\
119\end{array}$ & Same as maximum pressure & $\begin{array}{l}107 \\
113\end{array}$ & o & 109 \\
\hline T.M... & $\sigma^{7}$ & 127 & $\begin{array}{l}91 \\
91\end{array}$ & Same as maximum pressure & $\begin{array}{l}91 \\
93\end{array}$ & $\mathbf{0}$ & $\begin{array}{l}91 \\
93\end{array}$ & Same as maximum pressure & $\begin{array}{l}93 \\
89\end{array}$ & $\mathbf{0}$ & 113 \\
\hline$\overline{\text { G. McC..... }}$ & $0^{7}$ & 126 & $\begin{array}{l}92 \\
91\end{array}$ & Same as maximum pressure & $\begin{array}{l}83 \\
86\end{array}$ & $\mathbf{0}$ & $\begin{array}{l}80 \\
76\end{array}$ & Same as maximum pressure & $\begin{array}{l}78 \\
76\end{array}$ & o & \\
\hline D.S... & $\sigma^{7}$ & 132 & $\begin{array}{l}90 \\
94\end{array}$ & Same as maximum pressure & $\begin{array}{l}90 \\
96\end{array}$ & $\mathbf{0}$ & $\begin{array}{l}72 \\
64\end{array}$ & Same as maximum pressure & $\begin{array}{l}76 \\
70\end{array}$ & o & $\begin{array}{l}108 \\
106\end{array}$ \\
\hline N.W....... & $\%$ & 110 & $\begin{array}{l}101 \\
105\end{array}$ & $\overline{\text { Same as maximum pressure }}$ & $\begin{array}{l}83 \\
89\end{array}$ & 0 & $\begin{array}{l}94 \\
97\end{array}$ & Same as maximum pressure & $\begin{array}{l}89 \\
94\end{array}$ & $\mathbf{0}$ & $\begin{array}{l}85 \\
89\end{array}$ \\
\hline$\overline{\text { M.A....... }}$ & 8 & 111 & $\begin{array}{l}79 \\
79\end{array}$ & Same as maximum pressure & $\begin{array}{l}81 \\
85\end{array}$ & 0 & $\begin{array}{l}85 \\
89\end{array}$ & Same as maximum pressure & $\begin{array}{l}85 \\
87\end{array}$ & $\mathbf{0}$ & $\begin{array}{l}85 \\
87\end{array}$ \\
\hline$\overline{D . M} . \ldots \ldots$ & 9 & 105 & $\begin{array}{l}58 \\
60\end{array}$ & Same as maximum pressure & $\begin{array}{l}60 \\
60\end{array}$ & 0 & $\begin{array}{l}58 \\
56\end{array}$ & Same as maximum pressure & $\begin{array}{l}54 \\
52\end{array}$ & 0 & 67 \\
\hline M. H...... & 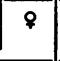 & 117 & $\begin{array}{l}129 \\
129\end{array}$ & Same as maximum pressure & $\begin{array}{l}122 \\
124\end{array}$ & $\mathbf{0}$ & $\begin{array}{l}115 \\
115\end{array}$ & Same as maximum pressure & $\begin{array}{l}110 \\
114\end{array}$ & 0 & $\begin{array}{l}110 \\
110\end{array}$ \\
\hline Average. & $\ldots$ & 119 & 96 & 96 & 90 & 0 & 89 & 89 & 85 & 0 & 99 \\
\hline
\end{tabular}




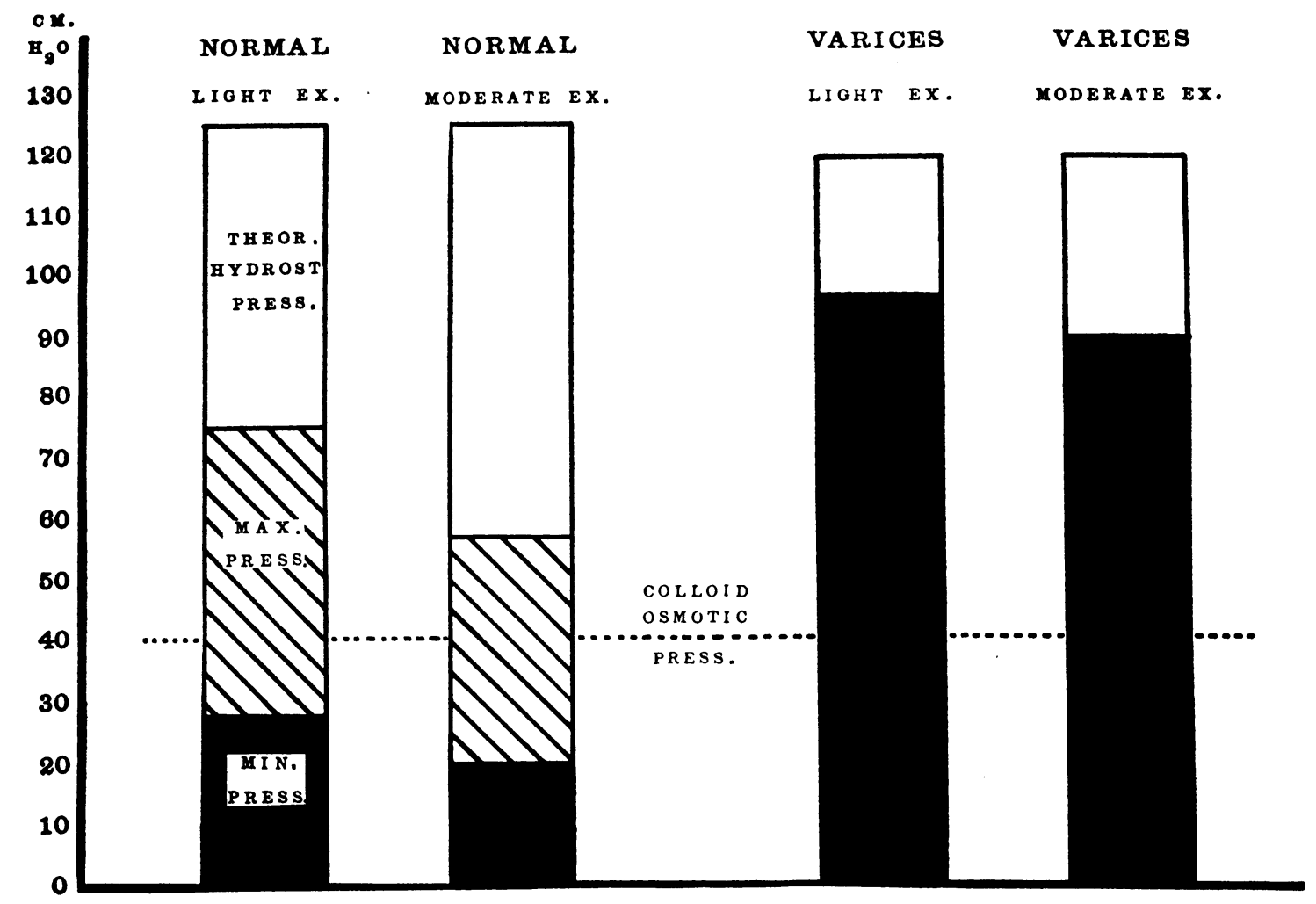

Fig. 3. Pressure Relationships at the Ankle Level during Walking, in Normal and Varicose Veins

The difference between the maximum and minimum pressures represents the pulsation pressure with each step; it is lacking in the varicose veins.

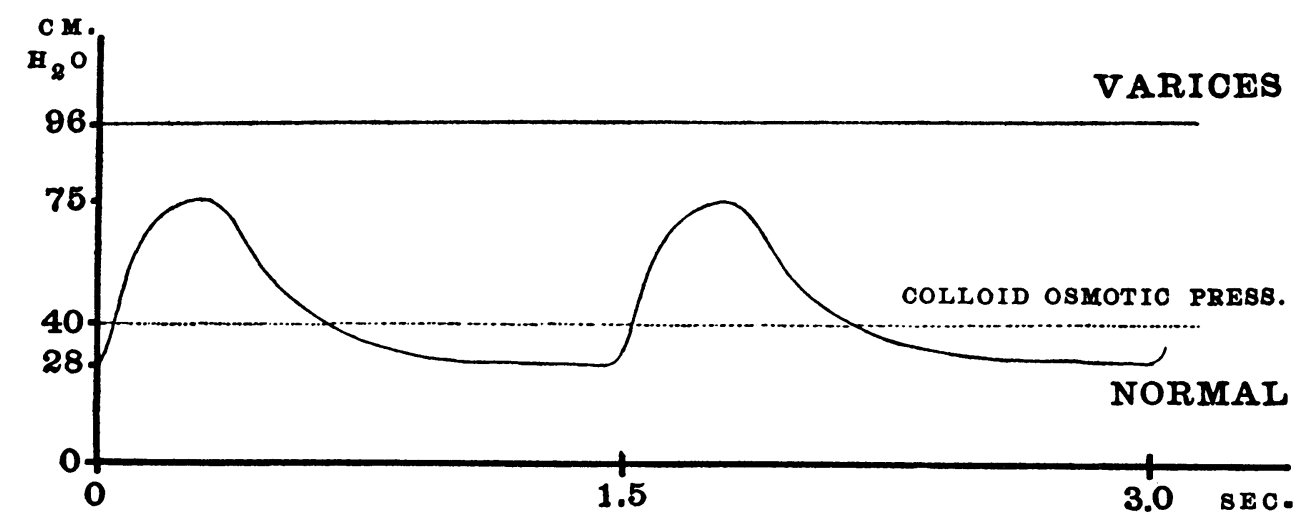

Fig. 4. Shows the Pressure Fluctuation in Normal Ankle Veins during Two Steps

Normally for two-thirds of the time of the step the pressure is below the colloid osmotic pressure of the blood. The sustained, high venous pressure found in varices during walking is shown. 
Both of these effects would be increased by the venous stasis present. Normal tissue elasticity would act in opposition to filtration of fluid from the capillaries. Presumably, as soon as the "tissue spaces" were filled with fluid, the elasticity of the walls of the spaces would oppose further filtration. This is supported by Waterfield (13), who found that changes in volume during standing in subjects in poor training, with fat, flabby legs, showed greater increases than was the case with subjects who were in training and who had tightly knit calves and ankles. Krogh, Landis and Turner (5) found that when tissue fluid had accumulated to the extent of more than $0.6 \mathrm{cc}$. per $100 \mathrm{cc}$. of arm tissue, venous obstruction of 15,20 and at times $30 \mathrm{~cm}$. $\mathrm{H}_{2} \mathrm{O}$ failed to increase further the accumulation. Probably at this point of "saturation," removal through lymphatics begins.

Tissue tension plus accelerated lymph flow must balance the action of the effective filtration pressure in the subjects studied, for gross edema did not appear. The explanation of this balance as due in any appreciable degree to a high tissue tension, in the absence of gross edema, is untenable for physical reasons. Since reabsorption into the capillaries is impossible because of the high pressures in them, the balance must be maintained by an increased lymph flow. It is evident from this data that a high, sustained venous pressure of the degree indicated above is not of itself adequate for the production of gross edema.

\section{SUM MARY}

Venous pressures at the ankle level have been measured during walking in subjects having incompetent valves of the great saphenous system. Gross edema was not present in the subjects studied. A gross filtration pressure of the order of $50 \mathrm{~cm} . \mathrm{H}_{2} \mathrm{O}$ in excess of the colloid osmotic pressure of the blood was shown to be present even during walking. The conditions present are in some respects comparable to those found in the presence of a prolonged partial venous obstruction. The normal reabsorption of tissue fluid at the venous end of the capillary as postulated and supported by many investigators is impossible here, and all of the tissue fluid must be carried off by the lymphatics. It is pointed out that failure of this compensating mechanism may be responsible for some of the severe complications of varicose veins. The data are discussed from the point of view of Starling's theory of the formation of tissue fluid.

\section{BIBLIOGRAPHY}

1. Beecher, H. K., Field, M. E., and Krogh, A., A method of measuring venous pressure in the human leg during walking. Skandinav. Arch $f$. Physiol., 1936, 73, 7.

2. Beecher, H. K., Field, M. E., and Krogh, A., The effect of walking on the venous pressure at the ankle. Skandinav. Arch. f. Physiol., 1936, 73, 133.

3. von Farkas, G., Utber die Wirkung des AlbuminGlobulin-Quotienten auf den osmotischen Druck des Serums. Ztschr. f. d. ges. exper. Med., 1926, 50, 410.

4. Govaerts, P., Influence de la teneur du sérum en albumines et en globulines sur la pression osmotique des protéines et sur la formation des oedemes. Bull. Acad. roy. de méd. de Belgique, 1927, 7, 356.

5. Krogh, A., Landis, E. M., and Turner, A. H., The movement of fluid through the human capillary wall in relation to venous pressure and to the colloid osmotic pressure of the blood. J. Clin. Invest., 1932, 11, 63.

6. Landis, E. M., Micro-injection studies of capillary blood pressure in human skin. Heart, 1929-30, 15, 209.

7. Landis, E. M., The capillary blood pressure in mammalian mesentery as determined by the microinjection method. Am. J. Physiol., 1930, 93, 353.

8. Landis, E. M., Jonas, L., Angevine, M., and Erb, W., The passage of fluid and protein through the human capillary wall during venous congestion. J. Clin. Invest., 1932, 11, 717.

9. Peters, J. P., Body Water. The Exchange of Fluids in Man. Charles C. Thomas, Baltimore, 1935.

10. Schade, $H$., Uber Quellungsphysiologie und Odementstehung. Ergebn. d. inn. Med. u. Kinderh., 1927, 32, 425.

11. Starling, E. H., On the absorption of fluid from the connective tissue spaces. J. Physiol., 1895-96, 19, 312.

12. Thompson, W. O., Thompson, P. K., and Dailey, M. E., The effect of posture upon the composition and volume of the blood in man. J. Clin. Invest., 1928, 5, 573.

13. Waterfield, R. L., The effect of posture on the volume of the leg. J. Physiol., 1931, 72, 121.

14. Youmans, J. B., Wells, H. S., Donley, D., and Miller, D. G., The effect of posture (standing) on the serum protein concentration and colloid osmotic pressure of blood from the foot in relation to the formation of edema. J. Clin. Invest., 1934, 13, 447. 